\title{
A Study on the Factors Affecting Decrease in the Government Corruption and Mediating Effects of the Development of ICT and E-Government-A Cross-Country Analysis
}

\author{
Kangwon Lee, Sang ok Choi *, Jinha Kim and Mijin Jung \\ Department of Science and Technology Studies, Korea University, Seoul 02841, Korea; \\ kangwonlee@koea.ac.kr (K.L.); jhkim74@kistep.re.kr (J.K.); mjjung@kiat.or.kr (M.J.) \\ * Correspondence: sangchoi@korea.ac.kr
}

Received: 10 May 2018; Accepted: 23 August 2018; Published: 3 September 2018

\begin{abstract}
Purpose: As the development of high technology, information and communications technology (ICT) and e-government has pursued improving efficiency, productivity, democracy, responsiveness and transparency in government, the demand for efficient government administration systems and government transparency has increased. Thus, this study aims to derive factors contributing to decreases in corruption based on a literature review, and to examine the relationship between e-government and government corruption through a cross-country analysis. Design/Methodology/Approach: This study first analyzed how government corruption in each country is influenced by e-government user status, governance, and regulations. With ICT and e-government development as mediating variables, the effects of various factors on government corruption were examined by country. That is, the mediating effects of ICT use and e-government development (telecommunication infrastructure, online service, e-participation) were assessed in order to define the relationship between users, governance, regulations and government corruption. This study ensured objectivity of data by utilizing statistics provided by credible organizations such as the Transparency International (TI), Organization for Economic Cooperation and Development (OECD) and United Nations (UN) and differs from past research in that it focused on the mediating effects of e-government. In this study, a cross-country analysis (with data from 120 countries), a three-step analysis of the mediating effects (Baron and Kenny, 1986) and a Sobel test (empirical analysis) were used. Results: The results of the analysis show a significant relationship between e-government user levels, governance, government regulation, and government corruption. In addition, the level of current ICT development and e-government partially mediated the effects of user levels, governance and government regulation on decreases in government corruption. These results show that the development of ICT and e-government mediate and contribute to a decrease in government corruption, and that increased utilization of ICT and monitoring government actions using such technologies will be one major factor in decreasing government corruption. Implications: These findings suggest an efficient and effective direction for future anti-corruption strategies in government policy making and implementation processes.
\end{abstract}

Keywords: mediating effects; cross-country analysis; ICT; e-government; government corruption

\section{Introduction}

The development of information and communications technology (ICT) has improved accessibility to vast amounts of information and has raised the level of openness around the world. This has affected not only the degree of ICT use by citizens, but also the administrative operations of 
governments. ICT has laid the foundation for governments to respond effectively to citizens' needs for administrative transparency and has paved the way for the implementation of e-government systems. Along with the establishment of e-government infrastructure, most countries have enhanced national competitiveness through the development of public services, thereby laying the foundation for maturing into world-leading ICT hubs.

Past research on e-governments has mainly discussed the correlation between trust in the government and administrative transparency or the level of national corruption, which is consistent with the purpose behind e-governments. Since the occurrence of corruption varies by country and class, and [1], studies have been confined to the aforementioned correlation and have failed to explore the causal relationship between e-government and government corruption [2]. The correlation between e-government and government corruption has been examined from three perspectives, namely, decrease in corruption, trigger of corruption, and no relation [2]. Most research has shown that e-governments have contributed to a decrease in government corruption. That is, the governments themselves make the administrative system more transparent using ICT and subject themselves to greater monitoring by the citizens, and this ultimately lowers the degree of corruption.

In some countries, a contradictory relationship was observed between e-government development and government corruption. For instance, Korea's e-government ranked first in the United Nations (UN) E-Government Survey in 2012 and 2014 [3], but the level of public trust in the government stood at $25 \%$ in 2013 and $34 \%$ in 2014 [4]. In terms of the corruption perceptions index (CPI), it fell from 37th place in 2015 to 52nd in 2016 [5]. What leads to this contradictory relationship?

This study was initiated based on the contradictory relationship between e-government development and government corruption. While past studies found that e-governments have had positive effects in decreasing government corruption, some factors may have been excluded in their discussions of government corruption. By examining previously unaccounted factors, this study may discover a new correlation between e-government development and government corruption. Most past studies focused on analyzing superficial factors and adopted a one-directional approach to the relationship between e-government and government corruption. From another perspective, it could be that there is little or no relationship between e-government and government corruption. This highlights the need to re-establish the relationship between the two factors, especially considering how recent advancements in ICT and the upcoming fourth industrial revolution have accelerated the development of e-governments.

The purpose of this study is to derive factors contributing to decreases in corruption based on a literature review, and to examine the relationship between e-government and government corruption through a cross-country analysis. Instead of taking a one-dimensional approach, this study first analyzed how government corruption in each country is influenced by e-government user status, governance, and regulations. With ICT and e-government development as mediating variables, the effects of various factors on government corruption were examined by country. That is, the mediating effects of ICT use and e-government development (telecommunication infrastructure, online service, e-participation) were assessed in order to define the relationship between users, governance, regulations and government corruption. This study ensured objectivity of data by utilizing statistics provided by credible organizations such as the the Transparency International (TI), Organization for Economic Cooperation and Development (OECD) and United Nations (UN) and differs from past research in that it focused on the mediating effects of e-government. Based on a multi-dimensional analysis of factors contributing to a decrease in government corruption, this study proposes anti-corruption strategies to be considered in the government policymaking process. 


\section{Background Literature}

\subsection{Development of ICT}

The premise of this study is that national informatization, based on ICT and the Internet, is a factor that increases government transparency. The level of informatization of a country is the degree of implementation and utilization of ICT and the Internet. It varies according to differing national requirements, leadership, economy, education, and cultural conditions. The South Korean government has defined the term "national informatization" in the Framework Act on National Informatization. According to the Act, the basic scope of informatization is national informatization, which can be classified into the following categories: Promotion of Public Informatization (Article 15), Promotion of Community Informatization (Article 16), and Support for Informatization of Private Sectors (Article 17). Article 3 of the Act states that national informatization is "the promotion of informatization by national agencies, local governments or public institutions, or support by such through informatization for the efficient conduct of activities in each sector of society" [6]. The main agent behind the promotion of national informatization are national agencies, and the purpose of attaining qualitative and quantitative growth in informatization is to benefit the citizens and improve the overall quality of life. National informatization is promoted by both public and private sectors in South Korea, and the e-government system has been introduced to systematize national information in the public sector [7].

Discussions on information technology and corruption have been mainly focused on administrative transparency. The issue of transparency has been examined in the context of corruption control as well as accessibility [8]. Many countries rely on ICT as a tool to enhance transparency and reduce corruption [9-11], and e-governments have been launched out of the belief that such systems will contribute to greater administrative transparency. In addition, transparency is an essential value in the establishment of a good government and good governance [12]. According to [13], the use of ICT under e-governance can reform and modernize the public sector, and it is utilized by governments as a tool to improve service quality and delivery. ICT-based e-governance enables good governance by involving more citizens in the decision-making process. Democratic governance is achieved via an increase in citizen participation and the stronger voice of the people. Recently, many researchers [14-18] have continued discussions on the increasing use of e-government for the purposes of improving accessibility of information, increasing transparency and accountability, and anti-corruption measures [9]. Discussions of transparency have shown that the Internet significantly reduces costs involved in the collection and distribution of government information [19], thereby enhancing the transparency of government activities. Studies have also looked at whether ICT-based informatization and e-government have helped to enhance government transparency and reduce corruption. ICT tools can enhance transparency and contribute to the creation of public value when transparency is defined as the publicity of all the acts of government and its representatives to provide civil society with relevant information in a complete, timely, and easily accessible manner [20]. Hence, Da Cruz et al., developed a municipal transparency index (MTI) through the analysis of local government information made available on official websites. Ref. [21] evaluate the role of ICT in improving transparency and accountability in 319 regional and local governments in the European Union (EU), measuring website performance in four dimensions: transparency, interactivity, usability, and maturity. While a general consensus on the effect of e-government on anti-corruption is yet to emerge, the implementation of e-government systems opens up a new possibility of reducing corruption by addressing the information symmetry between citizens and governments [22]. Since one of the main functions of e-governments is to provide the general public with more opportunities to access information and to improve their capacity for information processing and analysis, they allow less leeway for corruption arising from the government monopoly of information [22].

This study uses the ICT development index published by the International Telecommunications Union (ITU) as a mediating variable. The index measures the number of Internet users, and the use 
of ICT by households and businesses. Ref. [23] interpreted the index as a measure of information disparity among different countries, and applied it to his study of national informatization.

\subsection{Development of E-Government}

Advancements in ICT have not only boosted industrial development, national economies, and social progress, but have also accelerated the integration of e-government systems. Article 2 (1) of the South Korean Act on Electronic Government [24] defines electronic government as "a government that efficiently performs administrative affairs between administrative agencies and public institutions or for citizens by digitalizing administrative affairs of administrative agencies, etc., using information technology." In the early days of e-governments, there was a greater focus on quantitative growth, such as infrastructural expansion, online availability of administrative services, and development of new administrative services. Today, with governments interacting more actively with citizens and businesses, the scope of e-governments has expanded from online administrative services to providing public data.

While various opinions exist on the emergence of e-governments, they are generally traced to the start of the Clinton administration in 1993. The Clinton administration attempted to reinvent the public sector by applying ICT to government operations and services, which marked the start of the e-government system [25]. During the Dae-jung Kim administration, the South Korean government launched its e-government to improve the efficiency of its operations and services provided to citizens. Later, the Roh Moo-hyun administration expanded the e-government to all administrative affairs, thereby improving public access to information and ensuring the openness of data. The Lee Myung-bak administration and Park Geun-hye administration, in line with further developments in ICT, promoted the e-government system under various names such as "ubiquitous government", "mobile government", and "smart government" [4,26].

E-governments are aimed at improving the efficiency of administrative services through the integration of ICT, and at enhancing government transparency and accountability $[27,28]$. In this context, the United Nations (2001) [29] saw e-governments as a solution to corruption in the public sector. Ref. [30] stated that the e-government ICT systems, including internal management systems and accounting management systems, can prevent and expose government corruption. The development of ICT infrastructure, government transparency, and accountability are thus regarded as important criteria in determining the extent of government corruption.

Past research on e-governments and corruption have focused on the relationship between informatization and corruption, and many differing views exist on the influence of informatization on corruption. Informatization in the public sector was deemed as having a positive impact on corruption by [22,31], but as negative by [32,33]. According to [23], such inconsistencies result from examining the relationship with a focus only on informatization in the public sector, and not taking into account the development of ICT infrastructure. This means that corruption may be difficult to control in a country with weak ICT infrastructure, no matter how high the degree of government informatization. Thus, the development of ICT infrastructure is an important prerequisite for an effective e-government system against corruption.

Massive amounts of data have been generated and accumulated with the rapid development of ICT, and users can access such data easily through the Internet and Social Network Service (SNS) [34]. This increased access to information and the greater demand for the people's right to know have contributed to the disclosure of government information. The government, as part of its open information policy, has exerted efforts to engage citizens and enhance the transparency of state operations. Because state operations remained undisclosed to the public prior to the launch of the e-government systems, government transparency was inextricably linked to corruption [30]. Moreover, Ref. [25] found that citizen engagement and monitoring of the policymaking process helps to prevent the abuse of authority by government officials. The enhancement of government transparency through 
information disclosure in the public sector is expected to reduce the possibility of corruption in budget execution and policy implementation.

E-governments seek to improve transparency by making public information readily available, and this increase in transparency lowers the possibility of corruption while enforcing accountability [35]. That is, by engaging citizens in state affairs and providing them with the opportunity to monitor the government, the government and public officials operate with greater accountability [30]. The degree of government accountability can thus be determined based on to what degree services and information are provided through e-government websites, and how willing the government is in engaging citizens in the development of public policies [4]. As such, government accountability is presumed to have a direct influence on government corruption.

Many other studies have been conducted on the relationship between the level of e-government and government corruption. The factors directly influencing the level of e-government were found to be the users' education levels, economic wealth, government size, government accountability, and government regulations [22,36-39].

The factors required for e-government utilization, including ICT use, telecommunications infrastructure, online services, and participation, were variables that affected government corruption $[9,10,30]$. The following section provides a closer examination of the variables used in this study.

\subsection{Key Variables Affecting Government Corruption}

The key variables affecting government corruption, as used in empirical studies, are users' economic and education levels, governance, government regulations, and other factors.

\subsubsection{Level of Users (Education, GDP)}

This study determined the level of users based on education and economic development. According to [36], economically developed countries are more likely to have highly educated citizens, and a higher fear of exposure helps to lower corruption. The clear distinction between public and private roles in such countries contributes to a lower tolerance for corruption $[37,40]$ found that the level of corruption is lower in countries with higher GDP per capita. Ref. [41] obtained mixed results for the influence of economic wealth and income on corruption but confirmed the correlation between income and corruption. Ref. [22] regarded GDP and education as being closely related to corruption and selected the rate of increase in GDP and level of education as control variables. Ref. [23] assessed the economic environment using the country's rate of economic growth and GDP per capita. Ref. [42] used GDP per capita as a control variable for the state environment.

\subsubsection{Governance (Size, Voice and Accountability)}

Good governance is defined as "the manner in which power is exercised in the management of a country's economic and social resources for development" by the World Bank (1992) [43]. The first efforts to measure various aspects of governance emerged in the mid 1990s. Governance assessments for comparisons with major cities in other countries require multi-criteria. Refs. [43-45] show an example of a value tree containing the six dimensions of governance: voice and accountability, political stability, government effectiveness, regulatory quality, rule of law and control of corruption. This study examines the factors related to governance qualitatively and quantitatively in terms of government size and voice and accountability, respectively. The relationship between government size and corruption was verified in past empirical studies. Ref. [38] found a causal relationship between the budget size of a U.S. state-level government and corruption. The government is the largest supplier and consumer of the national economy and is highly likely to have exclusive benefits due to its monopolistic status [30]. Under the dimension of voice and accountability, government size was regarded as an influential factor. Ref. [46] identified three indicators of governance, including the respect of citizens and of the state for institutions that govern interactions among them. Ref. [39] presented six dimensions 
of governance, where voice and accountability captures the extent to which citizens can participate in selecting their government, and freedom of expression. Ref. [23] saw participation and accountability, government effectiveness, and the rule of law as indicators of governance quality and used those as control variables for governance.

\subsubsection{Regulations (Business and Credit Market Regulations)}

In addition to government size, regulations are seen as being closely related to corruption. According to [22,47-49], the greater and stronger the regulations, the lower the level of corruption. Refs. [50-52] found that barriers to market entry led to an expansion of corruption. Furthermore, Refs. [53,54] saw the government's regulatory function as being tied to corruption, while [55] found that corruption was more severe in countries with greater market intervention. The factors selected in past studies as having influence on government corruption include credit market regulations by [56], and credit and business regulations by $[22,30]$ chose credit regulations, labor market regulations, and general business regulations as influential factors.

\subsubsection{Other Control Variables (World Press Freedom, Political Rights, Civil Liberties)}

The main issue of interest in this study is whether government regulations affect government corruption. Factors affecting corruption have been broadly examined in past research. Since it is difficult to consider all variables, this study uses political factors (political rights, civil liberties, and freedom of press) as control variables. Political rights are measured using Freedom House's political rights index, obtained from an analysis of the electoral process, political pluralism and participation, and the functioning of the government. Civil liberties are measured using Freedom House's civil liberties index, measuring among categories such as freedom of expression and belief, and personal autonomy and individual rights. Freedom of the press is also based on reports by Freedom House. Ref. [57] saw the solidifying of democracy as contributing to a decrease in corruption, and [58] used political determinants as one of their control variables.

\subsection{Government Corruption}

As described above, the dependent variable in this study is the level of corruption in the government. Corruption is a social phenomenon that has long existed since the dawn of humanity. Anti-corruption acts have been enacted by many countries, including Hong Kong in 1948, and Singapore in 1960 [59]. The term "corruption" has been approached from different perspectives and is difficult to define in simple terms. While it is used interchangeably with irregularity, criminality, and irrationality, corruption is a broad term that extends beyond illegal acts or crimes when viewed in an academic context.

According to Article 2 (3) of the South Korean Act on the Prevention of Corruption [60], an "act of corruption" can fall under any of the following three categories. First, it is the act of any public official abusing his or her position or violating laws in connection with his/her duties to benefit him/herself or a third party. Second, it is the act of inflicting damages on the property of any public institution in violation of laws in the process of budget execution; the acquisition, management, or disposal of property; or entering into and executing a contract involving the relevant public institution as a party. Third, it is the act of coercing, urging, proposing and inducing any act referred to in the preceding paragraphs or concealing such an act. The South Korean Association for Public Administration defines corruption as an act of deviance against public interest, committed in an illegal and unethical manner for the purpose of gaining personal benefits [61].

The possibility of corruption is associated with the category and size of interests resulting from the control of a bureaucratic organization [59], and is closely related to politics, economy, society, and culture [62]. The trap of corruption, that is, how corruption causes poverty and vice versa, shows that the level of economic development should be considered when examining corruption [53]. Factors affecting corruption can be approached from various angles; one point of view is that democracy 
institutionalizes economic/political competition and helps to reduce adverse effects by preventing corruption [54]. The development of ICT has raised expectations of transparency in the public sector following the widespread use of ICT by businesses and governments.

The development and expansion of e-government systems have had positive effects, such as an increase in transparency in infrastructure development, corruption control, and bridging of information gaps [63]. This has highlighted the need for further research with the development of information technology as a new variable [56].

Transparency is used synonymously with anti-corruption [6], and according to [64], it is also seen as a tool that facilitates control of the government's internal affairs or establishes good governance. It is an indicator of the accessibility, openness and utility of information on government activities, and serves as a testimony to the accuracy of content and sources $[6,65]$ defined transparency as the acquisition of information by the public on the operations and structure of a specific institution and considered it synonymous with openness and disclosure. The Institute for Development of Freedom of Information (2011) [66] saw transparency as the provision of information on government responsibilities and undertakings to citizens.

Many studies have been conducted on various explanatory variables affecting government transparency, adopted as a dependent variable $[6,14,22,23,42,56,58,64]$. To perform an empirical analysis of government corruption, this study used the corruption perceptions index (CPI) published by Transparency International (TI) [67] as a dependent variable (Table 1).

Table 1. Major affective factors on government corruption.

\begin{tabular}{|c|c|}
\hline Classification & Affecting Factors and Existing Researchers \\
\hline \multirow{2}{*}{ Level of Government system users-Corruption } & GDP per capita and education, $[22,23,36]$ \\
\hline & GDP per capita $[37,41,42]$ \\
\hline \multirow{4}{*}{ Governance-Corruption } & Government size and budget size $[30,38]$ \\
\hline & Voice and accountability [39] \\
\hline & $\begin{array}{l}\text { Voice and accountability, political stability, government } \\
\text { effectiveness [45] }\end{array}$ \\
\hline & $\begin{array}{l}\text { Participation and accountability, government } \\
\text { effectiveness, and the rule of law as indicators of } \\
\text { governance quality, and used [23] }\end{array}$ \\
\hline \multirow{6}{*}{ Government Regulation-Corruption } & Regulation [22,47-49] \\
\hline & Barriers to market entry [50-52] \\
\hline & Government's regulatory function $[53,54]$ \\
\hline & Credit market regulations [56] \\
\hline & Credit and business regulations [22] \\
\hline & $\begin{array}{l}\text { Credit regulations, labor market regulations, and general } \\
\text { business regulations [30] }\end{array}$ \\
\hline \multirow{3}{*}{ ICT and E-Government } & E-participation [6] \\
\hline & ICT development index/ICT infrastructure/ICT use [23] \\
\hline & E-participation/online service $[9,30]$ \\
\hline
\end{tabular}

\section{Hypothesis, Research Models \& Statistical Methods}

\subsection{Hypothesis and Research Models}

Based on the aforementioned studies, the factors contributing to a decrease in government corruption are economic and educational status of e-government system users, governance, and government regulations. The mediating factors in the decrease of government corruption are ICT use indices: telecommunication infrastructure (TII), online services (OSI), and e-government 
participation (EPI). The following hypotheses are proposed to examine factors affecting government corruption and the mediating effects of ICT use and e-government.

First, Hypothesis 1 was proposed to analyze the relationship between the various factors and the actual decrease in government corruption. The factors tested were the e-government user status, governance, and government regulations.

Hypothesis 1 (H1). The higher the e-government users' status and governance quality, and the greater the relaxation of government regulations, the more positive the effect on decreasing government corruption.

Hypothesis 1-1 (H1-1). The higher the e-government users' status, the more positive the effect on decreasing government corruption.

(1) Education

(2) GDP

Hypothesis 1-2 (H1-2). The higher the quality of governance, the more positive the effect on decreasing government corruption.

(3) Government size

(4) Voice and accountability

Hypothesis 1-3 (H1-3). The greater the relaxation of government regulations, the more positive the effect on decreasing government corruption.

(5) Business regulations

(6) Credit market regulations

In examining based on Hypothesis 1, the research model shown below (see Figure 1) was formulated to examine the influence of e-government user status, governance and government regulations on the decrease of government corruption. Among the factors affecting government corruption, the e-government users' status was categorized by education and GDP. Governance was categorized by government size and voice and accountability, and government regulations by business regulations and credit market regulations. The control variables were world press freedom, political rights, and civil liberties.

Independent Variables

\begin{tabular}{|l|}
\hline $\begin{array}{l}\text { Level of } \\
\text { Government System Users } \\
\text { - Education index } \\
\text { - GDP }\end{array}$ \\
\hline $\begin{array}{l}\text { Governence } \\
\text { - Governments size } \\
\text { - Voice and accountability }\end{array}$ \\
\hline $\begin{array}{l}\text { Government Regulation } \\
\text { - Business regulations } \\
\text { - Credit market regulations }\end{array}$ \\
\hline
\end{tabular}

Dependent Variables

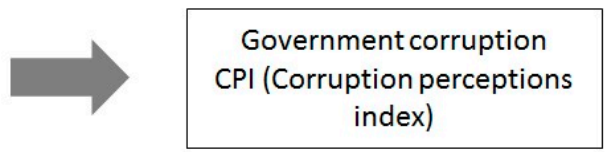

Figure 1. Research Model (A). Note: Structures affecting a decrease in government corruption.

Hypothesis 2 was proposed to analyze the mediating effects of ICT use and e-government in the decrease of government corruption. Based on past studies, the e-government development index 
(EDI) was divided into the telecommunication infrastructure index (TII), the online service index (OSI), and the e-participation index (EPI).

Hypothesis 2 (H2). The higher the level of ICT use and e-government, the more positive the effect on decreasing government corruption.

Hypothesis 2-1 (H2-1). The higher the level of ICT use, the more positive the effect on decreasing government corruption.

Hypothesis 2-2 (H2-2). The higher the level of telecommunication infrastructure (TII), the more positive the effect on decreasing government corruption.

Hypothesis 2-3 (H2-3). The higher the level of online services provided by the government, the more positive the effect on decreasing government corruption.

Hypothesis 2-4 (H2-4). The higher the level of e-government participation, the more positive the effect on decreasing government corruption.

In examining the influence of e-government user status, governance and government regulations on the decrease of government corruption, this study assumes that ICT use and e-government development will exhibit significant mediating effects. Based on Hypothesis 2, the research model shown below (see Figure 2) was formulated to analyze the mediating effects of ICT use and e-government development between government users' economic and educational levels, governance and government regulations, and government corruption. Under ICT development, only ICT use was considered, and ICT access and ICT skills were excluded to avoid repetition. Under e-government development, infrastructure was measured using the telecommunication infrastructure index (TII), government transparency using the online service index (OSI), and government accountability using the e-participation index (EPI). In particular, ICT use and e-government development have been identified as both dependent and independent variables contributing to a decrease in government corruption (Kim, T. et al., 2008; Choi, J., 2014; Moon, 2015), and play a mediating role in reducing corruption. The research model below was developed to analyze the mediating effects of ICT use and e-government development, and to test the proposed hypotheses.

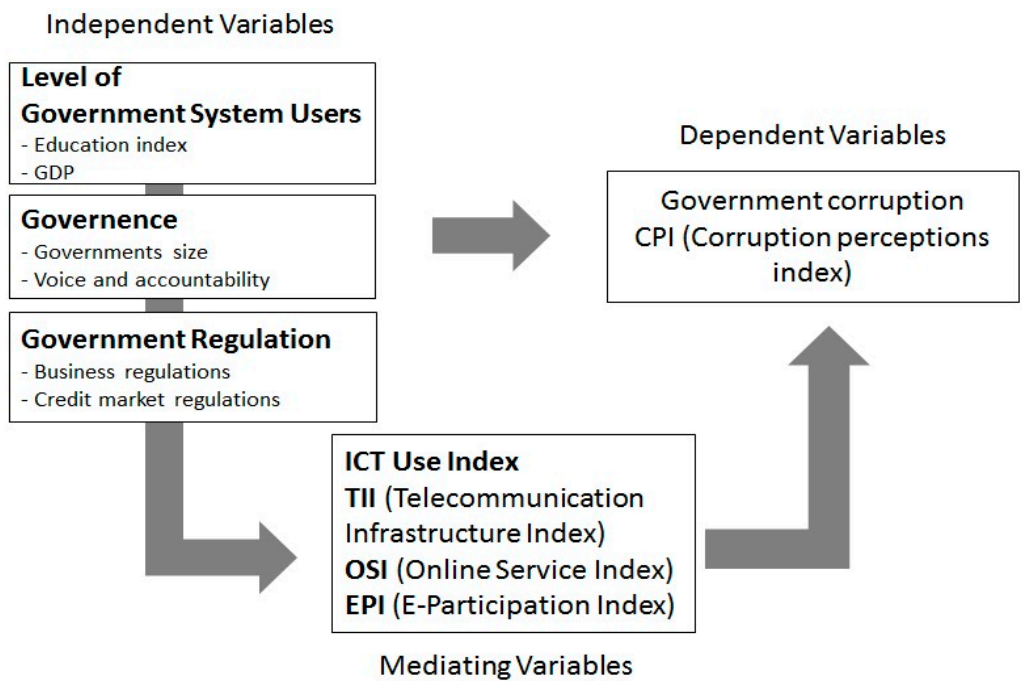

Figure 2. Research Model (B). Note: Mediating effects of information and communications technology (ICT) use, telecommunication infrastructure (TII), online service (OSI) and e-participation (EPI). 


\subsection{Data Collection and Methodology}

The final number of countries included in the analysis was 120 out of 176 after excluding those with missing values. Independent variables and mediating variables were based on 2014 reports by human development indicators, the United Nations Development Programme (UNDP) [68], the United Nations Statistics Division [69], World Bank Governance Matters VIII [70], the Fraser Institute [71], Reporters without Borders [72], Freedom House [73], the UN E-Government Survey [3], and International Telecommunication Union (ITU)'s Measuring the Information Society 2015 [74]. Dependent variables were based on 2016 reports by Transparency International (TI) [67].

For an empirical analysis of government corruption, this study used the corruption perceptions index (CPI) of Transparency International (TI) as a dependent variable. The corruption perceptions index (CPI) reports from 2016 were utilized in consideration of the causal relationship with independent variables (2014) and the time needed for independent relationships to affect dependent variables. The e-government users' status, adopted as an independent variable, was comprised of education level (education index, human development indicators, UNDP) and economic development (GDP per capita, UN Statistics Division). Governance was divided into government size (Fraser Institute), and voice and accountability (World Bank Governance Matters VIII). Fraser Institute's 2014 reports were used as a reference for government regulations, comprised of business regulations and credit market regulations.

The mediating variable of ICT use was based on ITU's Measuring the Information Society 2015. The e-government development index was based on the telecommunication infrastructure index (TII), online service index (OSI), and e-participation index (EPI) in the UN E-Government Survey 2014. The operational definition of each variable is given in Table 2.

Table 2. Key variables and source.

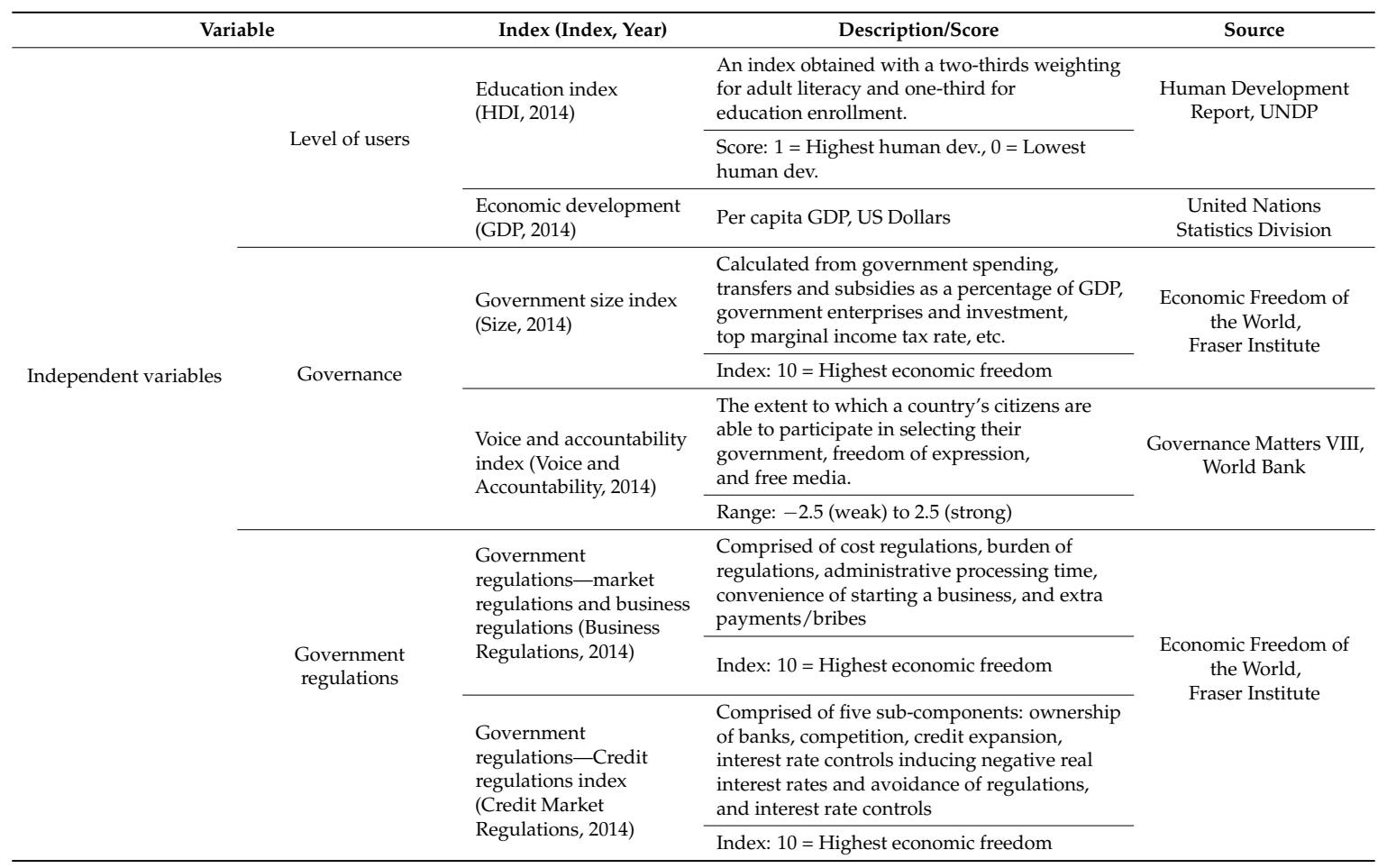


Table 2. Cont.

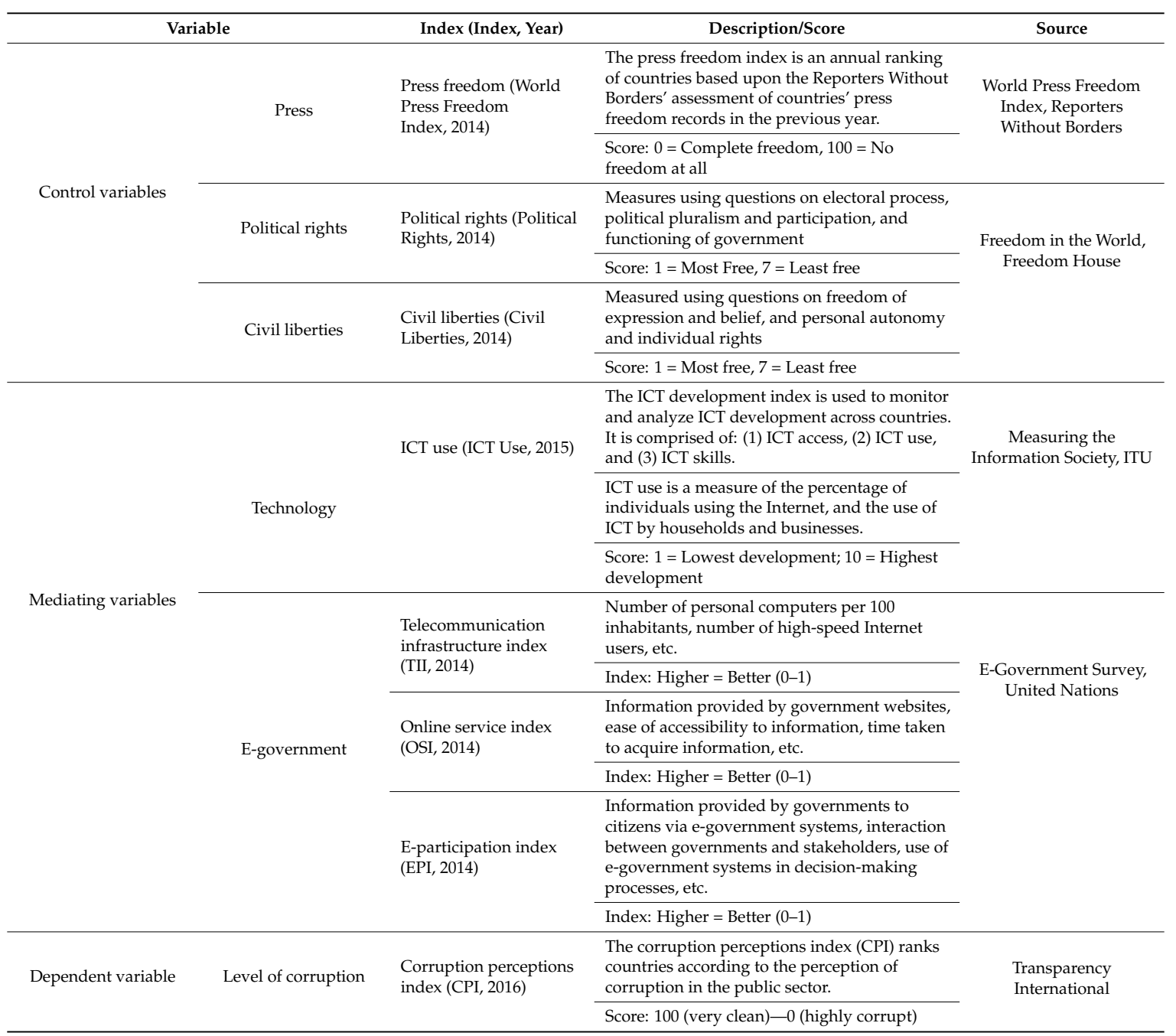

This study applied multiple regression analysis to test Hypothesis 1 , that is, to examine the effects of e-government user status, governance and government regulations on corruption decrease. To test the mediating effects of e-government development in Hypothesis 2, three steps proposed by Baron and Kenny (1986) were implemented. The reliability of the results was enhanced through an additional Sobel test, an interval estimation method that supplements the statistical significance of three-stage point estimation.

\section{Findings and Results}

The descriptive statistics for independent variables, mediating variables and dependent variables are provided in Table 3. Most variables had an absolute skewness below two and a kurtosis below 10, thus satisfying the assumption of normality. 
Table 3. Descriptive statistics for complete cases $(n=120)$.

\begin{tabular}{|c|c|c|c|c|c|c|c|c|}
\hline & Category/Variab & & Mean & S.D. & Skewness & Kurtosis & Min. & Max. \\
\hline \multirow{5}{*}{ Independent Variables } & \multirow{2}{*}{ Government user status } & Education level; HDI & 0.73 & 0.15 & -0.58 & 2.38 & 0.387 & 0.942 \\
\hline & & Economic development; GDP & 17,548 & 22,649 & 2.02 & 7.24 & 357 & 117,45 \\
\hline & Governance & Government size & 6.44 & 1.34 & -0.24 & 2.26 & 3.37 & 8.83 \\
\hline & \multirow{2}{*}{ Government regulation } & Business regulation & 6.26 & 0.74 & -1.1 & 6.36 & 3.25 & 7.93 \\
\hline & & Credit market regulation & 8.32 & 1.58 & -2.14 & 9.77 & 0 & 10 \\
\hline Control Variables & Civil liberties & Civil liberties & 3.08 & 1.69 & 0.27 & 1.87 & 1 & 7 \\
\hline \multirow{4}{*}{ Mediating Variables } & ICT & ICT use & 5.75 & 2.08 & -0.11 & 1.88 & 0.09 & 8.83 \\
\hline & \multirow{3}{*}{ E-government } & \multirow{3}{*}{$\begin{array}{l}\text { Telecommunication } \\
\text { infrastructure (TII), } \\
\text { online service (OSI) } \\
\text { e-participation (EPI) }\end{array}$} & 0.51 & 0.25 & 0.08 & 2.15 & 0 & 1 \\
\hline & & & 0.43 & 0.24 & 0.3 & 2.02 & 0.0266 & 0.935 \\
\hline & & & 0.51 & 0.25 & 0.13 & 2.15 & 0.0196 & 1 \\
\hline
\end{tabular}

In Step 1 of Baron and Kenny's steps for mediation, the regression coefficient must be statistically significant when dependent variables are regressed on independent variables. In Step 2, the regression coefficient must be significant when mediating variables are regressed on independent variables. In Step 3, the regression coefficient must be statistically significant when dependent variables are regressed on mediating and independent variables. The results support full mediation when the relationship between independent and dependent variables are not significant. Partial mediation is observed when the relationship is significant, and the absolute value of the regression coefficient has decreased (Baron and Kenny, 1986).

Step 1 in Table 4 is the result of testing Hypothesis 1. The proposed model, used to examine the effects of e-government user status, governance, and government regulations on corruption decrease, had an explanatory power $\left(\mathrm{R}^{2}\right)$ of 0.85 . Economic development, business regulations, and voice and accountability were found to be significant in decreasing government corruption at the $99.9 \%$ confidence interval. Government size was significant at $95 \%$, and education level at $90 \%$. Hypotheses 1-3 were partially supported, as credit regulations had no significant influence on corruption. The results partially supported Hypothesis 1 , which predicts that government corruption will decrease with e-government user status and governance quality, and greater relaxation of government regulations.

As can be seen from Step 2 of the three-step procedure proposed by Baron and Kenny (1986) in Table 3, education level and economic development had a significant influence on ICT use at the $99.9 \%$ confidence interval, and government size at $90 \%$. The results in Step 3 show the mediating effect of ICT use, which significantly mediated the relationship between the variables of education level, economic development, and government size, and a decrease in government corruption at the $99 \%$ confidence interval. More specifically, full mediation was observed between education level and corruption decrease, and partial mediation between economic development and corruption decrease. Under governance, partial mediation was observed between a reduction in government size and corruption decrease. The mediating effect on the relationship between education level and corruption decrease was significant at the $90 \%$ confidence interval in Step 1, but not significant in Step 3 , thus suggesting full mediation. For e-government user status, the mediating effect between economic development and corruption decrease was significant in all three stages at the $99.9 \%$ confidence interval. The unstandardized coefficient for economic development decreased from 0.0003 in Step 1 to 0.0002 in Step 3, which indicates that ICT use partially mediates the relationship between economic development and corruption decrease. Under governance, the mediating effect between government size and corruption decrease was significant at the 95\% confidence interval in Step 1,90\% in Step 2, and $95 \%$ in Step 3. The decrease in the absolute unstandardized coefficient for government size from -1.4058 in Step 1 to -1.139 in Step 3 shows that ICT use acts as a partial mediator between government size and decrease in government corruption. Since Step 2 revealed that ICT use was not 
significant in mediating the relationship between the dependent variables of voice and accountability and regulations, and decrease in corruption, it was excluded from the analysis of mediating effects. Thus, Hypothesis 2-1 was partially supported.

Table 4. Factors affecting decrease in government corruption and mediating effect of ICT use.

\begin{tabular}{|c|c|c|c|c|c|c|c|}
\hline \multicolumn{2}{|l|}{ Step } & \multicolumn{2}{|c|}{ Step 1} & \multicolumn{2}{|c|}{ Step 2} & \multicolumn{2}{|c|}{ Step 3} \\
\hline \multicolumn{2}{|c|}{ Dependent Variables } & \multicolumn{2}{|c|}{$\begin{array}{l}\text { Corruption Perceptions } \\
\text { Index, CPI }\end{array}$} & \multicolumn{2}{|c|}{ ICT Use } & \multicolumn{2}{|c|}{$\begin{array}{l}\text { Corruption Perceptions } \\
\text { Index, CPI }\end{array}$} \\
\hline Result & & $\beta$ & $t$-Value & $\beta$ & $t$-Value & $\beta$ & $t$-Value \\
\hline \multirow{6}{*}{ Independent Variables } & HDI & $15.6227^{\prime}$ & 1.9645 & $11.1977^{* * *}$ & 11.0189 & -7.9944 & -0.7164 \\
\hline & GDP & $0.0003^{* * *}$ & 4.8204 & $0.0000^{* * *}$ & 4.6449 & $0.0002^{* * *}$ & 3.3728 \\
\hline & Size & $-1.4058^{*}$ & -2.4498 & $-0.1265^{\prime}$ & -1.7245 & $-1.1390 *$ & -2.0247 \\
\hline & $\begin{array}{c}\text { Voice and } \\
\text { accountability }\end{array}$ & $16.6632 * * *$ & 3.9183 & -0.1158 & -0.2131 & $16.9074^{* * *}$ & 4.1089 \\
\hline & $\begin{array}{l}\text { Business } \\
\text { regulations }\end{array}$ & $6.9567^{* * *}$ & 6.2447 & 0.1569 & 1.1021 & $6.6258^{* * *}$ & 6.1143 \\
\hline & $\begin{array}{l}\text { Credit market } \\
\text { regulations }\end{array}$ & -0.5106 & -0.976 & -0.0405 & -0.6070 & -0.4252 & -0.8401 \\
\hline Mediating Variable & ICT use & & & & & $2.1091 * *$ & 2.9220 \\
\hline \multicolumn{2}{|l|}{$\mathrm{R}^{2}$} & \multicolumn{2}{|c|}{0.8574} & \multicolumn{2}{|c|}{0.8660} & \multicolumn{2}{|c|}{0.8678} \\
\hline \multicolumn{2}{|c|}{ F-value } & \multicolumn{2}{|c|}{73.5100} & \multicolumn{2}{|c|}{0.8660} & \multicolumn{2}{|c|}{78.9648} \\
\hline
\end{tabular}

As can be seen from the results for Step 2 in Table 5, education level had a significant effect on the telecommunication infrastructure (TII) at the $99.9 \%$ confidence interval, and business regulations at $90 \%$. The results for Step 3 show that the telecommunication infrastructure (TII) had a full mediating effect on the relationship between education level and government corruption, and a partial effect between business regulations and government corruption. More specifically, education level had a significant effect on government corruption in Step 1 at the $90 \%$ confidence interval, but was not significant in Step 3, thus suggesting full mediation. Business regulations were significant in Step 1, but the decrease in the unstandardized coefficient in Step 3 demonstrates that the telecommunication infrastructure (TII) acts as a partial mediator between business regulations and corruption decrease. GDP and credit regulations, on the other hand, had no mediating effect on the decrease in government corruption. Thus, Hypothesis 2-2 was partially supported.

Table 5. Factors affecting decrease in government corruption and mediating effect of the telecommunication infrastructure (TII).

\begin{tabular}{|c|c|c|c|c|c|c|c|}
\hline \multicolumn{2}{|l|}{ Step } & \multicolumn{2}{|c|}{ Step 1} & \multicolumn{2}{|c|}{ Step 2} & \multicolumn{2}{|c|}{ Step 3} \\
\hline \multicolumn{2}{|c|}{ Dependent Variables } & \multicolumn{2}{|c|}{$\begin{array}{c}\text { Corruption Perceptions } \\
\text { Index, CPI }\end{array}$} & \multicolumn{2}{|c|}{$\begin{array}{l}\text { Telecommunication } \\
\text { Infrastructure, TII }\end{array}$} & \multicolumn{2}{|c|}{$\begin{array}{c}\text { Corruption Perceptions } \\
\text { Index, CPI }\end{array}$} \\
\hline \multirow{5}{*}{ Independent Variables } & HDI & $15.6227^{\prime}$ & 1.9645 & $1.0018^{* * *}$ & 5.9415 & 0.9317 & 0.1068 \\
\hline & GDP & $0.0003^{* * *}$ & 4.8204 & 0.0000017 & 1.5455 & $0.0002 * * *$ & 4.4969 \\
\hline & $\begin{array}{c}\text { Voice and } \\
\text { accountability }\end{array}$ & $16.6632^{* * *}$ & 3.9183 & 0.0872 & 0.9669 & $15.3847^{* * *}$ & 3.7330 \\
\hline & $\begin{array}{l}\text { Business } \\
\text { regulations }\end{array}$ & $6.9567^{* * *}$ & 6.2447 & $0.0450^{\prime}$ & 1.9071 & $6.2961^{* * *}$ & 5.8238 \\
\hline & $\begin{array}{l}\text { Credit market } \\
\text { regulations }\end{array}$ & -0.5106 & -0.976 & -0.0010 & -0.0863 & -0.4966 & -0.9958 \\
\hline
\end{tabular}


Table 5. Cont.

\begin{tabular}{|c|c|c|c|c|c|c|c|}
\hline \multicolumn{2}{|c|}{ Step } & \multicolumn{2}{|c|}{ Step 1} & \multicolumn{2}{|c|}{ Step 2} & \multicolumn{2}{|c|}{ Step 3} \\
\hline \multicolumn{2}{|c|}{ Dependent Variables } & \multicolumn{2}{|c|}{$\begin{array}{l}\text { Corruption Perceptions } \\
\text { Index, CPI }\end{array}$} & \multicolumn{2}{|c|}{$\begin{array}{l}\text { Telecommunication } \\
\text { Infrastructure, TII }\end{array}$} & \multicolumn{2}{|c|}{$\begin{array}{l}\text { Corruption Perceptions } \\
\text { Index, CPI }\end{array}$} \\
\hline \multicolumn{2}{|c|}{ Result } & $\beta$ & $t$-Value & $\beta$ & $t$-Value & $\beta$ & $t$-Value \\
\hline Mediating Variable & $\begin{array}{c}\text { Telecommunication } \\
\text { infrastructure, } \\
\text { TII }\end{array}$ & & & & & $14.6652 * * *$ & 3.4154 \\
\hline \multicolumn{2}{|l|}{$\mathrm{R}^{2}$} & \multicolumn{2}{|c|}{0.8574} & \multicolumn{2}{|c|}{0.6372} & \multicolumn{2}{|c|}{0.8712} \\
\hline \multicolumn{2}{|c|}{ F-value } & \multicolumn{2}{|c|}{73.5100} & \multicolumn{2}{|c|}{21.4691} & \multicolumn{2}{|c|}{21.4691} \\
\hline
\end{tabular}

The results for Step 2 in Table 6 show that the online service (OSI) was significantly affected by education level and GDP at the $99.9 \%$ confidence interval, by government size at $95 \%$, and by voice and accountability at $90 \%$. In Step 3, the online service (OSI) had a full mediating effect for education level and voice and accountability, and a partial effect for GDP and government size. More specifically, education level had a significant effect on government corruption in Step 1 at the $90 \%$ confidence interval, but not in Step 3, thus suggesting full mediation. Both GDP and government size significantly affected government corruption in Step 3, but the decrease in the unstandardized coefficient in Step 3 shows that the online service (OSI) acts as a partial mediator between GDP and governance, and corruption decrease. voice and accountability significantly affected government corruption in Step 1 at the 99.9\% confidence interval, but not in Step 3, thus suggesting full mediation. Regulations did not have any mediating effect on decrease in government corruption. Thus, Hypothesis 2-3 was partially supported.

Table 6. Factors affecting decrease in government corruption and mediating effect of online service (OSI).

\begin{tabular}{|c|c|c|c|c|c|c|c|}
\hline \multicolumn{2}{|l|}{ Step } & \multicolumn{2}{|c|}{ Step 1} & \multicolumn{2}{|c|}{ Step 2} & \multicolumn{2}{|c|}{ Step 3} \\
\hline \multicolumn{2}{|c|}{ Dependent Variables } & \multicolumn{2}{|c|}{$\begin{array}{c}\text { Corruption Perceptions } \\
\text { Index, CPI }\end{array}$} & \multicolumn{2}{|c|}{ Online Service, OSI } & \multicolumn{2}{|c|}{$\begin{array}{c}\text { Corruption Perceptions } \\
\text { Index, CPI }\end{array}$} \\
\hline \multirow{5}{*}{ Independent Variables } & HDI & $15.6227^{\prime}$ & 1.9645 & $1.1045^{* * *}$ & 12.5607 & -5.7396 & -0.4714 \\
\hline & GDP & $0.0003^{* * *}$ & 4.8204 & $\underset{* * *}{0.0000024}$ & 4.1676 & $0.0002 * * *$ & 3.7209 \\
\hline & Size & $-1.4058^{*}$ & -2.4498 & $-0.0160 *$ & -2.5162 & $-1.0970^{\prime}$ & -1.8943 \\
\hline & $\begin{array}{c}\text { Voice and } \\
\text { accountability }\end{array}$ & $16.6632 * * *$ & 3.9183 & $0.0804^{\prime}$ & 1.7089 & 15.1090 & 3.5733 \\
\hline & $\begin{array}{l}\text { Business } \\
\text { regulations }\end{array}$ & $6.9567^{* * *}$ & 6.2447 & 0.0067 & 0.5459 & $6.8266^{* * *}$ & 6.2360 \\
\hline \multicolumn{2}{|l|}{$\mathrm{R}^{2}$} & \multicolumn{2}{|c|}{0.8574} & \multicolumn{2}{|c|}{0.8959} & \multicolumn{2}{|c|}{0.8640} \\
\hline \multicolumn{2}{|c|}{ F-value } & \multicolumn{2}{|c|}{73.5100} & \multicolumn{2}{|c|}{105.1400} & \multicolumn{2}{|c|}{105.1400} \\
\hline
\end{tabular}

The results for Step 2 in Table 7 show that education level has a significant effect on e-government participation (EPI) at the $99.9 \%$ confidence interval. In Step 3, e-government participation (EPI) acts as a full mediator between education level and corruption decrease.

More specifically, education level had a significant effect on corruption decrease in Step 1 at the 90\% confidence interval, but not in Step 3, thus suggesting full mediation. However, GDP, governance, 
and government regulations had no mediating effect on decrease in government corruption. Thus, Hypothesis 2-4 was partially supported.

Table 7. Factors affecting decrease in government corruption and mediating effect of e-participation (EPI).

\begin{tabular}{|c|c|c|c|c|c|c|c|}
\hline \multicolumn{2}{|l|}{ Step } & \multicolumn{2}{|c|}{ Step 1} & \multicolumn{2}{|c|}{ Step 2} & \multicolumn{2}{|c|}{ Step 3} \\
\hline \multicolumn{2}{|c|}{ Dependent Variables } & \multicolumn{2}{|c|}{$\begin{array}{l}\text { Corruption Perceptions } \\
\text { Index, CPI }\end{array}$} & \multicolumn{2}{|c|}{ E-Participation, EPI } & \multicolumn{2}{|c|}{$\begin{array}{l}\text { Corruption Perceptions } \\
\text { Index, CPI }\end{array}$} \\
\hline Result & & $\beta$ & $t$-Value & $\beta$ & $t$-Value & $\beta$ & $t$-Value \\
\hline \multirow{6}{*}{ Independent Variables } & HDI & $15.6227^{\prime}$ & 1.9645 & $0.9347^{* * *}$ & 4.9808 & 6.7498 & 0.7831 \\
\hline & GDP & $0.0003^{* * *}$ & 4.8204 & 7.64E-07 & 0.6227 & $0.0002^{* * *}$ & 4.7727 \\
\hline & Size & $-1.4058^{*}$ & -2.4498 & 0.0079 & 0.5856 & $-1.4810^{* *}$ & -2.6321 \\
\hline & $\begin{array}{c}\text { Voice and } \\
\text { accountability }\end{array}$ & $16.6632 * * *$ & 3.9183 & 0.1160 & 1.1560 & $15.5619^{* * *}$ & 3.7152 \\
\hline & $\begin{array}{l}\text { Business } \\
\text { regulations }\end{array}$ & $6.9567^{* * *}$ & 6.2447 & 0.0374 & 1.4213 & $6.6020^{* * *}$ & 5.9983 \\
\hline & $\begin{array}{l}\text { Credit market } \\
\text { regulations }\end{array}$ & -0.5106 & -0.976 & -0.0129 & -1.0488 & -0.3879 & -0.7548 \\
\hline Mediating Variable & $\begin{array}{l}\text { E-participation, } \\
\text { EPI }\end{array}$ & & & & & $9.4930 *$ & 2.3997 \\
\hline \multicolumn{2}{|l|}{$R^{2}$} & \multicolumn{2}{|c|}{0.8574} & \multicolumn{2}{|c|}{0.5368} & \multicolumn{2}{|c|}{0.8646} \\
\hline \multicolumn{2}{|l|}{ F-value } & \multicolumn{2}{|c|}{73.5100} & \multicolumn{2}{|c|}{14.1623} & \multicolumn{2}{|c|}{14.1623} \\
\hline
\end{tabular}

A summary of the mediating effects of ICT use and e-government development is presented in Table 8. ICT use, telecommunication infrastructure (TII), snline service (OSI) and e-participation (EPI) fully mediated the relationship between the education level of e-government users and corruption decrease. ICT use partially mediated the relationship between GDP and government size, and corruption decrease. Telecommunication infrastructure (TII) was a partial mediator between business regulations and decrease in government corruption.

The online service index (OSI) was a partial mediator for GDP and government size, and a full mediator between voice and accountability and corruption decrease.

Lastly, Table 9 shows the Sobel test results for the mediating effect analysis. Based on the three-step analysis of mediating effects proposed by Baron and Kenny (1986) [75], this study performed a Sobel test to determine the statistical significance of mediating effects and to obtain confidence intervals. Similar to how the three-step analysis relies on the decreasing absolute value of the regression coefficient for point estimation, the Sobel test performs interval estimation under the assumption that indirect effects follow a normal distribution. The ten pairs of independent and mediating variables observed to have a full or partial mediating effect in Baron and Kenny's three-step analysis were all found to be significant at the $90 \%$ confidence interval $(\alpha=0.1)$.

Table 8. Summary of results for mediating effect analysis.

\begin{tabular}{cccccc}
\hline \multicolumn{2}{c}{ Mediating Variables } & ICT Use & $\begin{array}{c}\text { Telecommunication } \\
\text { Infrastructure, TII }\end{array}$ & Online Service, OSI & E-Participation, EPI \\
\hline & HDI & Full mediation & Full mediation & Full mediation & Full mediation \\
GDP & Partial mediation & - & Partial mediation & - \\
Independent Variables & Size & Partial mediation & - & Partial mediation & - \\
& Voice and accountability & - & Full mediation & - \\
& Business regulations & - & - & - & - \\
\hline
\end{tabular}

First, ICT use showed significant mediating effects on the relationship between e-government user status and governance, and corruption decrease when examined using Baron and Kenny's three-step analysis, and acted as a mediator for education level, GDP and government size at the $99 \%$ confidence interval, according to the Sobel test. Second, the telecommunication infrastructure index (TII) showed 
significant mediating effects on the relationship between e-government user status and government regulations, and corruption decrease, when examined using Baron and Kenny's three step analysis. According to the Sobel test, it acted as a mediator between education level and corruption decrease at the $99 \%$ confidence interval, and as a partial mediator between business regulations and corruption decrease at the $99 \%$ confidence interval. Third, the online service (OSI) showed significant mediating effects on the relationship between e-government user status and governance, and corruption decrease, when examined using Baron and Kenny's three-step analysis, and acted as a mediator for level of users and governance at the $99.9 \%$ confidence interval, according to the Sobel test. Fourth, the e-government participation (EPI) showed significant mediating effects on the relationship between e-government user status and corruption decrease in Baron and Kenny's three-step analysis, and acted as a mediator between education level and corruption decrease at the $99 \%$ confidence interval, according to the Sobel test.

Table 9. Summary of Sobel test results.

\begin{tabular}{|c|c|c|c|}
\hline Independent Variables & Mediating Variables & $\mathrm{Z}$ & $p$-Value \\
\hline \multirow{4}{*}{ HDI } & ICT use & 6.0066 & $2 \times 10^{-9 * * *}$ \\
\hline & Telecommunication infrastructure, TII & 2.9032 & $0.0037^{* *}$ \\
\hline & Online service, OSI & 6.4405 & $1 \times 10^{-10 * * *}$ \\
\hline & E-government participation, EPI & 1.9562 & $0.0504^{\prime}$ \\
\hline \multirow{2}{*}{ GDP } & ICT use & 5.1314 & $3 \times 10^{-7 * * *}$ \\
\hline & Online service, OSI & 5.3902 & $7 \times 10^{-8 * * *}$ \\
\hline \multirow{2}{*}{ Size } & ICT use & -3.7852 & $0.0002 * * *$ \\
\hline & Online service, OSI & -3.9352 & $0.0001^{* * *}$ \\
\hline Voice and accountability & Online service, OSI & 6.4405 & $1 \times 10^{-10 * * *}$ \\
\hline Business regulations & Telecommunication infrastructure, TII & 3.8508 & $0.0001 * * *$ \\
\hline
\end{tabular}

\section{Conclusions, Research Limitations, and Implications}

The development of ICT, accompanied by administrative reforms and a demand for greater involvement in government affairs by citizens, has accelerated the emergence of e-government systems. E-government has grown more widespread with the expansion of information disclosure and higher demand for transparency in the public sector. Since citizen participation, information disclosure and public transparency are factors related to government corruption, the introduction of e-government was expected to have a positive effect on decreasing corruption. Some countries, however, were associated with low public trust and transparency despite having advanced e-governments.

This study examined the relationship between ICT use, e-government and government corruption based on the aforementioned contradiction. Instead of performing a one-dimensional analysis of the correlation between e-government and government corruption, this study analyzed various countries to determine the effects of ICT and e-government on corruption and identified the causes of these differences. It examined the relationship among e-government user status, governance, regulations and government corruption, and analyzed the mediating effects of e-government development in terms of ICT use, telecommunications infrastructure, and online services.

First, e-government user status, governance and government regulations were found to have a significant effect on decreasing government corruption. The significant factors under e-government user status were education level and GDP, and those under governance were government size, and voice and accountability. Under government regulations, the factor with a significant influence was business regulations. The factors with a full mediating effect on the relationship between education level and corruption decrease were ICT use, telecommunications infrastructure, online services, and e-government participation. ICT use acted as a partial mediator between GDP and corruption decrease, and between 
government size and corruption decrease. Telecommunications infrastructure partially mediated between business regulations and decrease in government corruption. Online services partially mediated between GDP and governance (government size, voice and accountability), and corruption decrease. In the analysis of factors affecting decrease in government corruption and the mediating effects of ICT use and e-government development, credit regulations did not show any statistical significance.

The political implications of this study are as follows. ICT use and e-government development were found to be mediators of e-government user status, government size, voice and accountability, and market regulations. As such, the results can serve as a valuable reference in the establishment of effective anti-corruption strategies. The role of the government is emphasized in most of the results. Since education level fully mediates the e-government's ICT use, telecommunications infrastructure, online services, and e-government participation, the level of education must be enhanced to decrease government corruption. Given that online services act as a direct mediator for voice and accountability, we can expect greater involvement of citizens and media in government affairs to have a positive effect on online service accessibility and information acquisition, thereby contributing to a decrease in government corruption. That is, government corruption can be reduced with citizens participating more actively in government affairs and with the media serving as a watchdog over the government. This will help to enhance the level of e-government development, and ultimately reduce corruption in the government. The government must relax market and business regulations in order to lower corruption. Major countries around the world are relaxing their regulations to keep up with rapid changes, including the advent of the fourth industrial revolution, and to remove obstacles in the development of new technology and the pioneering of new markets. More flexible regulations should be introduced for ICT-related private enterprises and markets. The expansion of ICT-related infrastructure will allow various entities to enjoy access to vast sources of information, thus reducing government corruption.

This study performed a cross-country analysis on the relationship among e-government user status, governance, regulations and government corruption, with e-government as the mediating variable in the contradictory relationship between e-government development and government corruption. Rather than adopting a typical one-dimensional approach, the factors affecting corruption decrease and their mediating effects were analyzed. However, this study is limited in that it did not explore the fundamental causes behind the contradictory relationship between e-government development and government corruption. The significance of this study lies in providing necessary information for the establishment of anti-corruption strategies and policies and serve as a basis for further investigation. Follow-up studies will be conducted to trace the fundamental causes behind the high level of corruption in countries with advanced e-governments, and the above results can be utilized to derive political factors and additional indicators.

Author Contributions: K.L. and S.o.C. conceived and designed the experiments; K.L., S.o.C., J.K. and M.J. performed the experiments; K.L. analyzed the data and contributed analysis tools; K.L., S.o.C., J.K. and M.J. wrote the paper.

Funding: The publishing fee of this paper was supported by the DGIST R\&D Program of the Ministry of Science, Technology and ICT (DGIST-18-IT-01).

Acknowledgments: This paper was received the best paper award at the SOItmC 2018 Conference and received support from DGIST for the publication fee (DGIST-IT-18-01).

Conflicts of Interest: The author declares no conflict of interest.

\section{References}

1. Robinson, M. Corruption \& Development; Frank Cass \& Co. Ltd.: London, UK, 1998.

2. Choi, H.J. A study of corruption vulnerabilities in e-government. In Research Report; The Korea Institute of Public Administration: Seoul, South Korea, 2011; Volume 2011, p. 362.

3. United Nations E-Government Knowledge Database. 2014. Available online: https:/ / publicadministration. un.org/egovkb/en-us/reports/un-e-government-survey-2014 (accessed on 28 August 2018). 
4. Yun, S.O. A study on the relationship between e-government and trust in government. J. Korean Assoc. Reg. Inf. Soc. 2015, 18, 29-58.

5. Suh, W.S.; Lee, D.R. A study on the perceptions of the government corruption. Korean Public Pers. Adm. Rev. 2016, 15, 1-27.

6. Kim, G. The effect relationship between national informatization and transparency: Analyzed latent growth modeling. J. Korean Assoc. Reg. Inf. Soc. 2015, 18, 1-33.

7. Myeong, S.H.; Kwon, Y.M.; Seo, H.J. Sustainable e-governance: The relationship among trust, digital divide, and e-government. Sustainability 2014, 6, 6049-6069. [CrossRef]

8. Choi, Y.H.; Myeong, S.H.; Lee, T.Y. An exploratory study of e-corruption vulnerabilities in embracing e-government. J. Cyber Commun. 2003, 11, 147-180.

9. Bertot, J.C.; Jaeger, P.T.; Grimes, J.M. Using ICTs to create a culture of transparency: E-government and social media as openness and anti-corruption tools for societies. Gov. Inf. Q. 2010, 27, 264-271. [CrossRef]

10. Bertot, J.C.; Jaeger, P.T.; Grimes, J.M. Promoting transparency and accountability through ICTs, social media, and collaborative e-government. Transform. Gov. People Process Policy 2012, 6, 78-91.

11. Von Waldenberg, W. Electronic government and development. Eur. J. Dev. Res. 2004, 16, 417-432.

12. Bannister, F.; Connolly, R. The trouble with transparency: A critical review of openness in e-government. Policy Internet 2011, 3, 1-30. [CrossRef]

13. Cho, Y.H.; Choi, B.D. E-government to combat corruption: The case of Seoul metropolitan government. Int. J. Public Adm. 2004, 27, 719-735. [CrossRef]

14. Anderson, T. E-government as an anti-corruption strategy. Inf. Econ. Policy 2009, 21, 201-210. [CrossRef]

15. Bhatnagar, S. E-government and access to information. In Global Corruption Report 2003; Transparency International: Washington, DC, USA, 2003.

16. Cullier, D.; Piotrowski, S.J. Internet information-seeking and its relation to support for access to government records. Gov. Inf. Q. 2009, 26, 441-449. [CrossRef]

17. Fuchs, M. Judging secrets: The role courts should play in preventing unnecessary secrecy. Adm. Law Rev. 2006, 58, 131-176.

18. Shim, D.C.; Eom, T.H. Anticorruption effects of information and communication technology (ICT) and social capital. Int. Rev. Adm. Sci. 2009, 75, 99-116. [CrossRef]

19. Roberts, A. Blacked out: Government Secrecy in the Information Age; Cambridge University Press: New York, NY, USA, 2006.

20. Da Cruz, N.; Tavares, A.; Marques, R.; Jorge, S.; De souse, L. Measuring local government transparency. In Public Management Review; Routledge: Abingdon, UK, 2016; Volume 18, pp. 866-893.

21. Pina, V.; Torres, L.; Royo, S. Is e-government promoting convergence towards more accountable local governments? Int. Public Manag. J. 2010, 13, 350-380. [CrossRef]

22. Kim, T.E.; Ahn, M.S.; Choi, Y.H. An analysis of the effect of e-government on corruption: Evidence through a cross-sectional and panel data analysis. Korean Public Adm. Rev. 2008, 42, 293-321.

23. Moon, J.W. Impact of the level of national informatization on corruption control: A multi-country comparative analysis. J. Korean Assoc. Reg. Inf. Soc. 2015, 18, 33-58.

24. South Korean Act on Electronic Government. Available online: http://www.law.go.kr/\%EB\%B2\%95\%EB\% A0\%B9/\%EA\%B5\%AD \%EA \%B0\%80\%EC \%A0\%95\%EB \%B3\%B4\%ED \%99\%94\%EA \%B8\%B0\%EB \%B3\% B8\%EB\%B2\%95 (accessed on 28 August 2018).

25. Osborne, D.; Gaebler, T. Reinventing Government: How the Entrepreneurial Spirit is Transforming the Public Sector; Beacon Press: Boston, MA, USA, 1 February 1993.

26. Park, E.H.; Lee, J.W. A study on policy literacy and public attitudes toward government innovationfocusing on Government 3.0 in South Korea. J. Open Innov. Technol. Mark. Complex. 2015, 1, 23. [CrossRef]

27. Computerization Promotion Committee. National Informatization Framework Plan; Computerization Promotion Committee: Seoul, South Korea, 2008.

28. South Korea E-Government Special Committee. E-Government White Paper; South Korea E-Government Special Committee: Seoul, Korea, 2003.

29. United Nations. Benchmarking E-Government: A Global Perspective; United Nations: New York, NY, USA, 2001.

30. Choi, J.W. E-government and corruption: A cross-country survey. J. Gov. Stud. 2014, 9, 1-23. [CrossRef] 
31. Song, H.J. The effects of electronic government projects on administrative transparency in Korea. Korean J. Policy Stud. 2002, 40, 110-134.

32. Heeks, R. Information Systems for Public Sector Management: Information Technology and Public Sector Corruption; Working Paper Series No. 4; Institute for Development Policy and Management: Antwerp, Belgium; University of Manchester: Hong Kong, China, 1998.

33. Mok, J.W.; Myeong, S.H.; Yun, T.B. Reduction of administrative corruption by e-government: Focusing on administrative red-tapes and information-communication technologies. Inf. Policy 2002, 9, 3-17.

34. Antoniadis, K.; Zafiropoulos, K.; Vrana, V. A method for assessing the performance of e-government twitter accounts. Future Internet 2016, 8, 12. [CrossRef]

35. Yun, S.O. The evaluation of citizen e-participation in e-government. J. Korean Assoc. Policy Sci. 2003, 7 , 79-103.

36. Lipset, S.M. Political Man: The Social Bases of Politics; Anchor Books: Garden City, NY, USA, 1960.

37. Treisman, D. The causes of corruption: A cross-national study. J. Public Econ. 2000, 76, 399-457. [CrossRef]

38. Goel, R.K.; Nelson, M.A. Corruption and government size: A disaggregated analysis. Public Choice 1998, 97, 107-120. [CrossRef]

39. Kaufmann, E.; Kraay, A.; Mastruzzi, M. Governance matters III: Governance indicators for 1996, 1998, 2000, and 2002. World Bank Econ. Rev. 2004, 18, 253-287. [CrossRef]

40. Huntington, S.P. Political Order in Changing Societies; Yale University Press: New Haven, CT, USA, 1968.

41. Montinola, G.R.; Robert, W.J. Sources of corruption: A cross-country study. Br. J. Polit. Sci. 2002, 32, 147-170. [CrossRef]

42. Wang, J.S. Effects of E-Government: A Focus on Governance Indicators. Korean J. Policy Stud. 2013, 51, 1-29.

43. World Bank. Governance and Development; World Bank: Washington, DC, USA, 1992.

44. Kaufmann, E.; Kraay, A.; Mastruzzi, M. The Worldwide Governance Indicators: A Summary of Methodology, Data and Analytical Issues; World Bank Policy Research Working Paper No. 5430; Cambridge University Press: Cambridge, UK, 2010.

45. Da Cruz, N.; Marques, R. New development: The challenges of designing municipal governance indicators. In Public Money and Management; Routledge: Abingdon, UK, 2013; Volume 33, No. 3, pp. 209-213.

46. Kaufmann, E.; Kraay, A.; Mastruzzi, M. Governance Matters: From Measurement to Action. Available online: https:/ / www.imf.org/external/pubs/ft/fandd/2000/06/pdf/kauf.pdf (accessed on 27 August 2018).

47. Bardhan, P. Corruption and development: A review of issues. J. Econ. Lit. 1997, 35, 1320-1346.

48. Gerring, J.; Thacker, S. Political institutions and corruption: The role of unitarism and parliamentarism. Br. J. Polit. Sci. 2004, 34, 295-330. [CrossRef]

49. Lederman, D.; Loayza, N.; Sores, R.R. Accountability and Corruption: Political Institutions Matter; World Bank Working Paper 2708; World Bank: Washington, DC, USA, 2001.

50. Broadman, H.G.; Recanatini, F. Seeds of Corruption—Do Market Institutions Matter; World Bank Policy Research Working Paper 2368; Springer: Washington, DC, USA, 1999.

51. Djankov, S.; La Porta, R.; Lopez de Silanes, F.; Shleifer, A. The regulation of entry. Q. J. Econ. 2002, 117, 1-37. [CrossRef]

52. Svensson, J. Eight questions about corruption. J. Econ. Perspect. 2005, 19, 19-42. [CrossRef]

53. Rose-Ackerman, S. Corruption and Government: Causes, Consequences, and Reform; Cambridge University Press: New York, NY, USA, 1999.

54. Schleifer, A.; Robert, W.V. Corruption. Q. J. Econ. 1993, 108, 599-617. [CrossRef]

55. Ades, A.; Tella, R.D. National champions and corruption: Some unpleasant interventionist arithmetic. Econ. J. 1997, 107, 1023-1042. [CrossRef]

56. Shin, H.J.; Jeong, Y.B.; Chong, H.J.; Hur, S.J. The analysis of influence between E-government and corruption. In Proceedings of the International Conference on Government Innovation and Human Resources Development, Seoul, Korea, 14 December 2007; pp. 327-338.

57. Nas, T.F.; Price, A.C.; Weber, C.T. A policy-oriented theory of corruption. Am. Polit. Sci. Rev. 1986, 80, 107-119. [CrossRef]

58. Choi, S.K.; Jung, K.H. Empirical study on e-government and corruption: Transparency as a key moderator. J. Korean Assoc. Reg. Inf. Soc. 2014, 17, 29-59. 
59. Suh, M.G. Determinants of corruption perceptions: A comparative analysis of Asian experiences. Asia Rev. 2018, 7, 3-31. [CrossRef]

60. South-Korean Act on the Prevention of Corruption. Available online: http://www.law.go.kr/lsInfoP.do? 1siSeq=70236\#0000 (accessed on 28 August 2018).

61. Kim, Y.J. The autonomous anti-corruption measures in public organizations. Korean Assoc. Corrupt. Stud. 2005, 10, 1-16.

62. World Bank. World Development Report; Oxford University Press: Oxford, UK, 2017.

63. Kim, J.H.; Choi, W.J.; Park, G.O. Effects of ICT dissemination on social infrastructure and national economy. In Proceedings of the Korean Academic Society of Business Administration Conference, Seoul, Korea, 18 August 2014; pp. 3333-3350.

64. Jung, Y.D.; Eom, S.J.; Bae, K.P.; Kim, D.S. Institutionalization for improving transparency in Korea. Korean Polit. Sci. Rev. 2012, 46, 31-53.

65. Etzioni, A. Is transparency the best disinfectant? J. Polit. Philos. 2010, 18, 389-404. [CrossRef]

66. Institute for Development of Freedom of Information. E-Governance and E-Transparency: International Tendencies and Georgia. 1 March 2011. Available online: https://idfi.ge/public/ migrated/uploadedFiles/files/Chapter\%201\%20eng.pdf (accessed on 27 August 2018).

67. Trasnparency International. Corruption Perception Index; Trasnparency International: Berlin, Germany, 2016.

68. UNDP. Human Development Report; UNDP: New York, NY, USA, 2014.

69. United Nations Statistics Division Database. 2014. Available online: http:/ / data.un.org/Search.aspx?q=GDP (accessed on 28 August 2018).

70. World Bank. Governance matters VIII. In Worldwide Governance Indicators; World Bank: Washington, DC, USA, 2014.

71. Fraser Institute. Economic Freedom of the World: 2014 Annual Report; Fraser Institute: Vancouver, BC, Canada, 2014.

72. Reporters without Borders. World Press Freedom Index; Marquette University: Milwaukee, WI, USA, 2014.

73. Freedom House. Freedom in the World; Freedom House: Washington, DC, USA, 2014.

74. ITU. Measuring the Information Society; ITU: Geneva, Switzerland, 2015.

75. Baron, R.M.; Kenny, D.A. The moderator-mediator variable distinction in social psychological research: Conceptual, strategic, and statistical considerations. J. Personal. Soc. Psychol. 1986, 51, 1173-1182. [CrossRef]

(C) 2018 by the authors. Licensee MDPI, Basel, Switzerland. This article is an open access article distributed under the terms and conditions of the Creative Commons Attribution (CC BY) license (http://creativecommons.org/licenses/by/4.0/). 